\title{
Permian non-marine bivalves of the Falkland Islands and their paleoenvironmental significance
}

\author{
Marcello G. SIMÕES, Fernanda QUAGLIO, Lucas V. WARREN, Luiz E. ANELLI, \\ Philip STONE, Claudio RICCOMINI, Carlos H. GROHMANN and Marlei A. C. \\ CHAMANI
}

Alcheringa: An Australasian Journal of Palaeontology, 2012, DOI:10.1080/03115518.2012.688682. Vol. 36, 543-554.

\begin{abstract}
We describe the occurrence of non-marine bivalves in exposures of the Middle Permian (Capitanian) Brenton Loch Formation outcrop on the southern shore of Choiseul Sound, East Falklands. The bivalves are associated with ichnofossils and were collected from beds in the upper part of the formation, within a $25 \mathrm{~cm}$ thick interval of dark siltstones and mudstones with planar-lamination, overlain by massive sandstones. The shells are articulated, with the valves either splayed open or closed. At the top of the succession, mudstone beds nearly $1.5 \mathrm{~m}$ above the bivalve-bearing layers yielded well-preserved Glossopteris sp. cf. G. comminis leaf fossils. The closed articulated condition of some shells indicates preservation under high sedimentation rates with low residence time of bioclasts at the sediment/water interface. However, the presence of specimens with splayed shells is usually correlated to the slow decay of shell ligament in oxygendeficient bottom waters. The presence of complete carbonized leaves of Glossopteris associated with the bivalve-bearing levels also suggests a possibly dysoxic-anoxic bottom environment. Overall, our data suggest that the bivalves were preserved by abrupt burial,
\end{abstract}


possibly by distal sediment flows into a Brenton Loch lake, and may represent autochthonous to parautochthonous fossil accumulations. The shells resemble those of anthracosiids and are herein assigned to Palaeanodonta sp. aff. P. dubia, a species also found in the Permian succession of the Karoo Basin, South Africa. Our results confirm that (a) the true distributions in space and time of all Permian non-marine (freshwater) bivalves are not yet well known, and (b) there is no evidence for marine conditions in the upper part of the Brenton Loch Formation.

Marcello G. Simões [profmgsimoes@gmail.com], Instituto de Biociências, Universidade Estadual Paulista, Distrito de Rubião Junior, CP. 510, 18.610-000, Botucatu, SP, Brazil; Fernanda Quaglio [quaglio@usp.br] Instituto de Geociências, Universidade de São Paulo, Programa de Pós-graduação em Geoquímica e Geotectônica, 05.508-080, São Paulo, SP, Brazil; Lucas Warren [lvwarren@yahoo.com], Instituto de Geociências, Universidade de São Paulo, Cidade Universitária, 05.508-080, São Paulo, SP, Brazil; Luiz E. Anelli [anelli@usp.br], Instituto de Geociências, Universidade de São Paulo, Cidade Universitária, 05.508-080, São Paulo, SP, Brazil; Philip Stone [psto@bgs.ac.uk], British Geological Survey, Murchison House, West Mains Road, Edinburgh EH9 3LA, UK; Claudio Riccomini [riccomin@usp.br], Instituto de Geociências, Universidade de São Paulo, Cidade Universitária, 05.508-080; Carlos Henrique Grohmann [guano@usp.br], Instituto de Geociências, Universidade de São Paulo, Cidade Universitária, 05.508-080, São Paulo, SP, Brazil; Marlei Chamani [marlei.chamani@gmail.com], Instituto de Geociências, Universidade de São Paulo, 
Programa de Pós-graduação em Geoquímica e Geotectônica, 05.508-080, São Paulo, SP, Brazil 